\title{
Flavobacterium psychrophilum, invasion into and shedding by rainbow trout Oncorhynchus mykiss
}

\author{
Jari Madetoja ${ }^{1, *}$, Pia Nyman $^{1}$, Tom Wiklund ${ }^{2}$ \\ ${ }^{1}$ Institute of Parasitology, Department of Biology, Åbo Akademi University, BioCity, Artillerigatan 6, 20520 Åbo, Finland \\ ${ }^{2}$ Danish Institute for Fisheries Research, Fish Disease Laboratory, Stigbøjlen 4, 1870 Frederiksberg C, Denmark
}

\begin{abstract}
The infection route of Flavobacterium psychrophilum into rainbow trout Oncorhynchus mykiss was studied using bath and cohabitation challenges as well as oral challenge with live feed as a vector. Additionally, the number of bacterial cells shed by infected fish into the surrounding water was determined in the cohabitation experiment and in challenge experiments at 3 different water temperatures. The experiments showed that skin and skin mucus abrasion dramatically enhanced the invasion of $F$. psychrophilum into the affected fish in bath and cohabitation challenges. Disruption of the skin is discussed as an important invasion route for F. psychrophilum into the fish. The shedding rate of $F$. psychrophilum by infected fish was associated with water temperature and the mortality of the infected fish. High numbers of $F$. psychrophilum cells were released into the water by dead rainbow trout during a long time period compared to the numbers of cells shed by live fish. The results emphasise the importance of removing dead and moribund fish from rearing tanks in order to diminish the infection pressure against uninfected fish in commercial fish farms. In immunohistochemical examinations of organs and tissues of orally infected fish, F. psychrophilum cells were detected in only 1 fish out of 31 studied. Mortality of the orally challenged fish was not observed in the experiment.
\end{abstract}

KEY WORDS: Flavobacterium psychrophilum $\cdot$ Rainbow trout $\cdot$ Bath challenge $\cdot$ Cohabitation challenge $\cdot$ Oral challenge $\cdot$ Shedding rate

\section{INTRODUCTION}

Flavobacterium psychrophilum (previously Cytophaga psychrophila and Flexibacter psychrophilus) is the causative agent of BCWD (bacterial cold water disease) and RTFS (rainbow trout fry syndrome) and causes serious disease outbreaks world-wide, mainly in farmed salmonid fish in freshwater. Although this pathogen is frequently present in salmonid fish farms, the transfer mechanisms of $F$. psychrophilum from infected into uninfected fish are still not completely understood. A direct vertical transfer of F. psychrophilum from infected brood fish to the offspring has been suggested (Brown et al. 1997, Ekman et al. 1999). There is also some evidence of a horizontal transfer of

*E-mail: jari.madetoja@abo.fi the pathogen from infected into non-infected fish (Borg 1948, Holt 1987, Madsen \& Dalsgaard 1999). However, it is still unknown whether F. psychrophilum is invading the fish through the skin, the gills or the intestinal tract.

The skin of fish serves as the first barrier against invading microorganisms. Numerous gland cells present in the skin epidermis produce mucus, which may contain specific and non-specific immune components such as immunoglobulins, lysozyme, complement, C-reactive protein, lectin, and haemolysin (Ingram 1980, Ellis 1981, Fletcher 1982).

Mechanical injuries in the skin of the trunk or the fins have been indicated as a plausible entrance port of Flavobacterium psychrophilum into the fish (Borg 1948, Holt 1987). Such injuries may interfere with the defence mechanisms enhancing the attachment, colonisation and invasion of attacking pathogens present 
in the water. Bacteria may originate from 2 sources: from populations of cells growing and dividing in the water using nutrients present in the environment or from a population of cells emitted directly from infected dead or living fish.

In several studies it has been shown that artificially infected fish subsequently will emit bacteria to the surrounding water environment (Bullock \& Stuckey 1977 , McCarthy 1977, Michel 1980, Rose et al. 1989, Enger et al. 1992, McKibben \& Pascho 1999). The infection pressure these bacteria constitute on healthy fish depends on the shedding rate from the infected fish. So far detailed studies on the shedding rate of Flavobacterium psychrophilum by infected fish are lacking.

The bacteria residing in the water column most probably will be attached to solid planktonic particles and/or consumed by zooplankton, which subsequently will serve as food for fish fry. In a previous study, the fish pathogenic bacterium Vibrio anguillarum has been successfully used for oral infection of juvenile turbot Scophthalmus maximus using Artemia nauplii as vectors (Grisez et al. 1996). The infection by Flavobacterium psychrophilum through the gastrointestinal tract of naive fish has not previously been investigated.

The aim of this study was to investigate shedding rate of Flavobacterium psychrophilum into water by experimentally infected fish and to study invasion of the pathogen into rainbow trout Oncorhynchus mykiss with skin lesions using bath and cohabitation exposure. In addition, possible invasion of F. psychrophilum through the intestinal tract was studied.

\section{MATERIALS AND METHODS}

Bacterial strains and cultivation. The Finnish strain T1-1 of Flavobacterium psychrophilum, originally isolated from the brain of rainbow trout suffering from RTFS, was used for bath and cohabitation challenges and shedding rate experiments. The Danish strain 950106-1/1 (Madsen \& Dalsgaard 1999) of F. psychrophilum, isolated from the internal organs of a rainbow trout during a clinical outbreak of RTFS in a freshwater farm, was used for studying the oral transfer of F. psychrophilum. The strains were stored in tryptone yeast extract salts (TYES) broth $(0.4 \%$ tryptone, $0.05 \%$ yeast extract, $0.05 \% \mathrm{MgSO}_{4} \cdot 7 \mathrm{H}_{2} \mathrm{O}, 0.02 \% \mathrm{CaCl} \cdot 2 \mathrm{H}_{2} \mathrm{O}$, $\mathrm{pH} 7.2)$ supplemented with $15 \%(\mathrm{v} / \mathrm{v})$ sterile glycerol at $-70^{\circ} \mathrm{C}$. For each experiment the bacteria were thawed and inoculated on TYES agar (TYES broth + $1.5 \%$ agar), and 1 to 3 colonies were transferred into TYES broth and incubated for 2 to $3 \mathrm{~d}$ at $15^{\circ} \mathrm{C}$ with shaking. The cells were harvested and washed twice with sterile phosphate buffered saline (PBS, pH 7.2) by centrifugation at $2500 \times g$ for $10 \mathrm{~min}$ at $15^{\circ} \mathrm{C}$. After the final centrifugation the cells were re-suspended in sterile PBS and immediately used in the experiments. The number of bacteria (expressed as colony forming units, CFU) in the suspension was determined using 10 -fold serial dilutions and plate count technique on TYES agar.

Fish. Rainbow trout for the bath challenge, cohabitation challenge and shedding rate experiments (weight $\sim 0.2 \mathrm{~g}$ ) were obtained from a commercial freshwater fish farm in Finland without any previous history of infection with Flavobacterium psychrophilum. The fish were kept in a $0.225 \mathrm{~m}^{3}$ fibreglass tank with continuously flowing well water of $10^{\circ} \mathrm{C}$. Prior to each experiment the fish were transferred to aquaria containing aerated well water and acclimatised for a minimum of 3 to $5 \mathrm{~d}$. Fish were fed ad libitum with a commercial (Ewos) feed throughout the experiments.

Rainbow trout (weight 2 to $4 \mathrm{~g}$ ) for possible oral transmission of Flavobacterium psychrophilum were previously obtained from a freshwater rainbow trout farm in Denmark, where RTFS or CWD has never been demonstrated, and kept in re-circulated tap water. For the experiments the fish were transferred to $10 \mathrm{l}$ aquaria at 12 to $13^{\circ} \mathrm{C}$ and fed a commercial feed (Dansk Ørredfoder A/S) throughout the experiments.

Polyclonal antiserum against Flavobacterium psychrophilum. For specific detection of F. psychrophilum in fish tissue and aquarium water using epifluorescence microscopy, rabbit polyclonal antiserum against F. psychrophilum strain T1-1 was prepared according to the method of Lancefield et al. (1975) modified by Lorenzen \& Karas (1992). In order to eliminate a slight cross-reaction of the anti-T1-1 serum observed with yellow-pigmented, non-characterised bacterial isolates biochemically different from F. psychrophilum (Wiklund et al. 2000), absorption of the antiserum was done by the following method: Two cross-reactive isolates were cultivated in separate tubes containing TYES broth for $3 \mathrm{~d}$ at $15^{\circ} \mathrm{C}$ with gentle shaking. The cultures were centrifuged at $2500 \times g$ for $15 \mathrm{~min}$ at $15^{\circ} \mathrm{C}$ and the bacteria were washed twice with PBS ( $\mathrm{pH}$ 7.2). After the second washing, the pellets were resuspended in $10 \mathrm{ml}$ PBS and pooled, and the cells were killed by autoclaving $\left(20 \mathrm{~min}, 121^{\circ} \mathrm{C}\right)$. The suspension was centrifuged as above, the supernatant was discarded and $1 \mathrm{ml}$ of the rabbit antiserum was added. The suspension was vortexed and incubated for $2 \mathrm{~h}$ at $37^{\circ} \mathrm{C}$ following incubation overnight at $4^{\circ} \mathrm{C}$ on a shaker. Subsequently the suspension was centrifuged as above, and the supernatant was collected and centrifuged at $10000 \times g$ for $20 \mathrm{~min}$ at $15^{\circ} \mathrm{C}$. Finally, the supernatant (antiserum) was sterile filtered $(0.22 \mu \mathrm{m}$, Millipore) and stored at $-20^{\circ} \mathrm{C}$ until used.

The specificity of absorbed antiserum was tested against several Flavobacterium psychrophilum strains 
(including F. psychrophilum type strain NCIMB $1947^{\mathrm{T}}$ ), Flexibacter aquatile (NCIMB 8694 ${ }^{\mathrm{T}}$ ), Flavobacterium columnare (NCIMB 2248 ${ }^{\mathrm{T}}$ ), Flavobacterium branchiophilum (ATCC $33035^{\mathrm{T}}$ ), Aeromonas salmonicida subsp. salmonicida, Yersinia ruckeri, Listonella (Vibrio) anguillarum and Pseudomonas anguilliseptica by the slide agglutination method.

Enumeration of Flavobacterium psychrophilum in experimental water. The numbers of F. psychrophilum in the water samples from the cohabitation and the shedding rate experiments were determined by a double-staining technique, as described by Hoff (1988), with some modifications. Ten $\mathrm{ml}$ volumes of water samples were filtered through a $25 \mathrm{~mm}$ diameter (18.4 mm diameter of filtering capacity) and $0.2 \mu \mathrm{m}$ pore size polycarbonate filter (Millipore, GTTP 02500) using a 12-funnel sampling manifold filter holder (Millipore). The filters were pre-stained before use by soaking for at least $30 \mathrm{~min}$ in a solution containing $0.2 \%(\mathrm{w} / \mathrm{v})$ irgalan black (CIBA-GEIGY) in $2 \%$ acetic acid and thereafter flooded with sterile Milli-Q water. After filtration of water samples the filters were washed 3 times with $2 \mathrm{ml}$ sterile Milli-Q water, placed in sterile petri dishes and allowed to dry. The filters were overlaid with $50 \mu \mathrm{l}$ absorbed anti-F. psychrophilum (T1-1 strain) serum diluted 1:100 in sterile PBS and incubated for $20 \mathrm{~min}$ at room temperature. After incubation, the filters were washed again with sterile Milli-Q water and allowed to dry, followed by staining of the DNA of F. psychrophilum with $250 \mu \mathrm{l} \mathrm{4}$, 6diamidino-2-phenylindole (DAPI, Sigma) at a final concentration of $1 \mu \mathrm{g} \mathrm{ml}^{-1}$ for $5 \mathrm{~min}$ at room temperature. Thereafter washing with sterile Milli-Q water was repeated and filters were covered with $50 \mu \mathrm{l}$ of fluorescein isothiocyanate (FITC) conjugated swine anti-rabbit antibodies (DAKO, F0205) diluted 1:100 in sterile PBS. After 20 min incubation in the dark, washing was repeated and the filters were placed on microscope slides, mounting medium was added (PBSglycerol, 1:1) and they were covered with cover glasses. The number of F. psychrophilum were determined at $1000 \times$ magnification from the same filters using an epifluorescence microscope (Leitz Aristoplan) with an OSRAM HBO 100 W/2 mercury short arc lamp as a light source. A filterblock D (BP 355-425 excitation filter, RKP 455 dichromatic mirror, LP 460 suppression filter) was used for viewing DAPI staining, and a filterblock E4 (BP 436/7 excitation filter, RKP 475 dichromatic mirror, LP 490 suppression filter) was used for viewing FITC staining. The numbers of fluorescing F. psychrophilum cells were counted in 20 randomly chosen microscope fields. The numbers of F. psychrophilum $\mathrm{ml}^{-1}$ in the water sample were calculated by multiplying the average number of bacteria observed per field by the total number of fields on a filter
(6750). The numbers of cells obtained was then divided by the $10 \mathrm{ml}$ filtered water volume. A minimum detection limit of 34 cells $\mathrm{ml}^{-1}$ in the water samples was obtained with this technique. One of the yellowpigmented bacterial strains biochemically different from $F$. psychrophilum, used for absorption of the antiT1-1 serum, was used as a negative control and F. psychrophilum strain T1-1 was included as a positive control in all analyses for controlling the specificity of the antiserum.

Bath challenge. In order to examine the influence of dermal incision and non-intact mucus layer on the susceptibility of rainbow trout to Flavobacterium psychrophilum 6 groups of fish (weight $0.4 \pm 0.1 \mathrm{~g}$ ) were used. All fish in each group were anaesthetised using benzocaine (ethyl p-aminobenzoate, $40 \mathrm{mg} \mathrm{l}^{-1}$, Sigma) before treatment. The dermis of the fish $(\mathrm{n}=41)$ in Group 1 (referred to as 'Skin wounded') was wounded with a 1 to $2 \mathrm{~mm}$ long incision on the left side of the fish, immediately below the dorsal fin using a sterile scalpel. The skin mucus layer between the head and the dorsal fin on the left side of the fish (approximate area $40 \mathrm{~mm}^{2}$ [n = 41]) in Group 2 (referred to as 'Nonintact skin mucus') was removed using a paper towel. The fish $(\mathrm{n}=40)$ in Group 3 (referred to as 'Noninjured') were not injured in any way. The time from treatment of the fish to bath challenge was approximately $1 \mathrm{~h}$. All 3 groups were bathed in well water containing $3.8 \times 10^{6} \mathrm{CFU} \mathrm{ml} \mathrm{m}^{-1}$ of strain T1-1 for $1 \mathrm{~h}$ with aeration. Three groups of 20 fish each (Groups 4, 5 and 6) served as controls and were given the same treatment as the fish in Groups 1, 2 and 3 respectively, but 'bathed' in well water without $F$. psychrophilum for $1 \mathrm{~h}$. After bathing, the fish in Groups 1, 2 and 3 were each separated into 2 replicates and kept in aerated aquaria containing $10 \mathrm{l}$ of static well water. The fish in Groups 4, 5 and 6 were kept in 3 separate aquaria. The water in the aerated aquaria was changed regularly during the experiment. The water temperature during the experiment was 11 to $12^{\circ} \mathrm{C}$. The mortality of challenged fish was monitored for up to $21 \mathrm{~d}$ after exposure. All dead fish were collected daily and tissue samples from their spleen, kidney and skin ulcer (if any) were inoculated on TYES agar plates, which were incubated at $15^{\circ} \mathrm{C}$ for at least $7 \mathrm{~d}$. Tissue samples from the survivors from Group 1 and from 5 survivors from the other groups were also inoculated on TYES agar. Bacteria forming yellow colonies on the agar plates typical to F. psychrophilum were identified using immunostaining and epifluorescence microscopy (Lorenzen \& Karas 1992).

In order to examine the effect of high, intermediate and low doses of Flavobacterium psychrophilum in the bath challenge, 6 groups of 20 (2 replicate groups per bacterial dilution) 'Skin wounded' rainbow trout 
(weight $0.6 \pm 0.1 \mathrm{~g}$ ) were bath challenged with 3 different dilutions $\left(6.0 \times 10^{5}, 6.0 \times 10^{4}\right.$ and $6.0 \times 10^{2} \mathrm{CFU}$ $\mathrm{ml}^{-1}$ ) of strain T1-1 as described above. The 'Skin wounded' control group ( $\mathrm{n}=20$ fish group ${ }^{-1}, 2$ replicates) was bathed in water without F. psychrophilum. Mortality of the infected fish was recorded daily and the experiment was terminated after $21 \mathrm{~d}$. Presence of F. psychrophilum in dead and surviving fish was examined as described previously.

Cohabitation challenge. In order to examine the waterborne route for transmission of Flavobacterium psychrophilum from infected to non-infected fish, cohabitation challenge experiments were done using 'Skin wounded', 'Non-intact skin mucus' and 'Noninjured' fish (weight $1.0 \pm 0.2 \mathrm{~g}, 20$ fish per treatment, 2 replicates) as recipients as described in the bath challenge experiment. Three groups of 20 fish each given the same treatment as the fish in 'Skin wounded', 'Non-intact skin mucus' and 'Non-injured' groups served as controls. Five fish per aquarium with the anal fin clipped for identification were used as donors. The donor fish were injected subcutaneously (s.c.) with $5.5 \times 10^{5} \mathrm{CFU}_{\text {fish }}{ }^{-1}$ of strain T1-1 of F. psychrophilum or with PBS in the control groups. The fish of each treatment were kept in separate aquaria containing 101 of static aerated well water. The infective load of $F$. psychrophilum in the different aquaria, containing donor and recipient fish, was measured using immunofluorescence staining as described previously. Water samples $(10 \mathrm{ml})$ from a depth of $2 \mathrm{~cm}$ were taken from the aquaria, using a sterile syringe, 1, 3, 5, 7, 9, 11, 13, $15,17,19$, and $21 \mathrm{~d}$ after injection of the donor fish. The samples were stored for a maximum of $24 \mathrm{~h}$ at $4^{\circ} \mathrm{C}$ before filtering and immunostaining. The whole water volume in each aquarium was changed after the sampling. The water temperature during the experiment was 11 to $12^{\circ} \mathrm{C}$. The presence of $F$. psychrophilum in dead and surviving fish was examined as described earlier.

Shedding rate experiments. In order to examine the shedding rate of Flavobacterium psychrophilum by infected fish, 3 experiments were done with rainbow trout infected by s.c. injection, intraperitoneal (i.p.) injection and bath challenge.

Subcutaneous injection: The shedding rate of Flavobacterium psychrophilum by s.c. infected fish was studied at 3 temperatures, 4,11 and $15^{\circ} \mathrm{C}(3.9 \pm 0.2$, $11.3 \pm 0.3$ and $15.3 \pm 0.3^{\circ} \mathrm{C}$ ). Rainbow trout (weight $1.6 \pm 0.5 \mathrm{~g}$ ) were injected s.c. with $3.2 \times 10^{4} \mathrm{CFU}$ of strain T1-1 in $50 \mu \mathrm{l}$ PBS. For each temperature 15 fish challenged with $F$. psychrophilum and 10 fish injected with only PBS, serving as control fish, were transferred to 5 separate aquaria each containing 5 fish, which were kept as previously described. In order to examine the shedding rate of bacterial cells, the injected fish were transferred from the aquaria to plastic containers of $3000 \mathrm{ml}$ fresh well water free of F. psychrophilum 1, 3, 5, 7, 10 and 14 d post-challenge. Furthermore, injected fish kept at $4^{\circ} \mathrm{C}$ were also transferred to plastic containers 18, 21 and $24 \mathrm{~d}$ post-challenge. After $1 \mathrm{~h}$ the fish were removed from the plastic containers and samples of water for enumeration of $F$. psychrophilum were taken from a depth of $2 \mathrm{~cm}$ using a $10 \mathrm{ml}$ sterile syringe. The samples were stored for a maximum of $24 \mathrm{~h}$ at $4^{\circ} \mathrm{C}$ before filtering and were treated as previously described. The shedding rate of $F$. psychrophilum from infected fish was calculated as previously described and the results are reported as number of cells shed fish ${ }^{-1} \mathrm{~h}^{-1}$. The well water in the plastic containers was changed and containers were cleaned after every transfer of fish. Moribund and dead fish from the aquaria were collected daily and tissue samples from spleen, kidney, skin ulcer (if present), intestine, eye and brain were inoculated on TYES agar plates, which were incubated at $15^{\circ} \mathrm{C}$ for at least $7 \mathrm{~d}$. The identity of bacteria forming yellow colonies on the agar plates was tested with the method described previously.

Intraperitoneal injection: Rainbow trout $(\mathrm{n}=15$, weight $1.7 \pm 0.5 \mathrm{~g}$ ) were injected i.p. with $50 \mu \mathrm{l}$ PBS containing $1.3 \times 10^{5} \mathrm{CFU}$ of Flavobacterium psychrophilum strain T1-1 or with PBS in the control group ( $\mathrm{n}=$ 10). The experiment was done at $11^{\circ} \mathrm{C}$ with conditions as described in the s.c. injection challenge. Samples of water from the plastic containers for enumeration of F. psychrophilum cells were taken and treated as described previously.

Bath challenge: The shedding rate of Flavobacterium psychrophilum by bath infected fish was studied at $11^{\circ} \mathrm{C}$. Rainbow trout $(\mathrm{n}=15$, weight $1.7 \pm 0.5 \mathrm{~g})$ were bath challenged in well water containing $2.6 \times$ $10^{6} \mathrm{CFU} \mathrm{ml}^{-1}$ of F. psychrophilum strain T1-1 for $1 \mathrm{~h}$ and control fish $(\mathrm{n}=10)$ were 'bathed' in well water without F. psychrophilum. Samples of the water from the plastic containers for the enumeration of F. psychrophilum cells were taken and treated as described previously.

Release of Flavobacterium psychrophilum from dead and infected rainbow trout. The number of $F$. psychrophilum cells released from dead fish, previously infected with F. psychrophilum, into the water, was studied in the following experiment. Five and 4 s.c. infected fish from 2 shedding rate experiments done at 4 and $11^{\circ} \mathrm{C}$, respectively, were kept in well water at 4 and $11^{\circ} \mathrm{C}$ and transferred at irregular intervals after death into a plastic container containing $500 \mathrm{ml}$ of well water where they remained for $1 \mathrm{~h}$. Samples of water taken from the plastic containers for enumeration of F. psychrophilum were treated as described previously. 
Infection of zooplankton and rainbow trout. A possible oral route transfer of Flavobacterium psychrophilum into rainbow trout was studied by using a laboratory culture of the zooplankton Daphnia magna as a vector. A 3 d old culture of strain 950106-1/1 of F. psychrophilum was washed twice with PBS, resuspended into sterile medium M4 (Elendt \& Bias 1990), adjusted to an absorbance of 1.1 (at $520 \mathrm{~nm}$ ) corresponding to $\sim 10^{9} \mathrm{CFU} \mathrm{ml} \mathrm{m}^{-1}$ and further 10-fold diluted into the same medium, giving $10^{8} \mathrm{CFU} \mathrm{ml^{-1 }}$. D. magna (1 specimen $\mathrm{ml}^{-1}$ ) was added to this bacterial suspension which was incubated at $15^{\circ} \mathrm{C}$ for $12 \mathrm{~h}$. After incubation the $D$. magna were washed 3 times with sterile PBS and transferred into medium M4. Rainbow trout ( $\mathrm{n}=$ 25) were individually fed with $5 \mathrm{D}$. magna incubated with F. psychrophilum. As negative controls, rainbow trout ( $\mathrm{n}=10$ ) were each fed with $5 \mathrm{D}$. magna, incubated in medium M4 without F. psychrophilum. Fish injected i.p. with strain 950106-1/1 (5 × 10 $\left.{ }^{4} \mathrm{CFU}_{\text {fish }}{ }^{-1}\right)$ were included as positive controls $(n=6)$. The experiment was repeated 3 times and the orally challenged group ( 5 fish aquarium ${ }^{-1}$ ) and the negative and positive control group (1 group aquarium ${ }^{-1}$ ) were held in aerated aquaria with static tap water at 12 to $13^{\circ} \mathrm{C}$. A part of the water in the aquaria was changed daily. Mortality of the fish was monitored and dead fish removed from the aquaria. In order to examine the presence of $F$. psychrophilum in different tissues of fish challenged by infected D. magna, 5 out of 25 infected fish and 2 out of 10 negative control fish were sacrificed $2 \mathrm{~h}, 1 \mathrm{~d}$ and $7 \mathrm{~d}$ post-challenge. Dead and sacrificed fish were fixed by injecting $0.1 \mathrm{ml} 4 \%$ buffered formalin into the abdominal cavity and then transferring the whole fish into the same fixative.

Detection of Flavobacterium psychrophilum in zooplankton and rainbow trout. The presence of the bacterial cells in infected Daphnia magna and in tissues of a fraction of the sacrificed fish was examined using an immunohistochemical technique described by Lorenzen \& Karas (1992). Absorbed rabbit antiserum against F. psychrophilum strain T1-1, diluted as described earlier, was used. The spleen, intestine, liver, heart and kidney of infected fish were processed for histology and decalcified (Bruno \& Poppe 1996), dehydrated samples were subsequently cut and the sections were stained immunohistochemically. The number of $F$. psychrophilum in and on D. magna was estimated by the following experiment: Twenty-five $D$. magna were incubated in medium M4 containing $\sim 10^{8} \mathrm{CFU} \mathrm{ml}{ }^{-1}$ of strain $950106-1 / 1$ for $12 \mathrm{~h}$ at $15^{\circ} \mathrm{C}$. After incubation $D$. magna were washed twice with sterile medium M4 and transferred into $1 \mathrm{ml}$ of sterile medium M4. D. magna were subsequently comminuted using a mortar, and the suspension was 10-fold serially diluted into sterile medium M4. The numbers of F. psychrophilum in the suspension were estimated by epifluorescence microscopy and the plate count technique on TYES agar. For the microscopical studies $10 \mu \mathrm{l}$ of a 1:100 dilution of the suspension was pipetted into the well of a special slide (Novakemi, $6 \mathrm{~mm}$ well, 10-207). The sample was fixed with $3 \%$ paraformaldehyde and immunostained. Absorbed rabbit antiserum against F. psychrophilum strain T1-1, diluted as described earlier, was used. The sample was mounted with a PBS-glycerol (1:1) and overlaid with cover glass.

\section{RESULTS}

\section{Specificity of absorbed antiserum against Flavobacterium psychrophilum}

The absorbed antiserum raised against strain T1-1 of Flavobacterium psychrophilum reacted only with tested F. psychrophilum strains.

\section{Bath challenge}

In the bath challenge experiments cumulative mortality in the 'Non-intact skin mucus' group (average $27 \%$; replicates 19 and $35 \%$ ) was much lower than in the 'Skin wounded' group (average $95 \%$; replicates 90 and $100 \%$ ), although the mortality in the 2 groups occurred almost within the same time range (Fig. 1a,b) Mortality did not occur in the 'Non-injured' group. Dead fish in the 'Skin wounded' and 'Non-intact skin mucus' groups had deep open lesions extending from the point where skin was wounded or mucus was removed. Flavobacterium psychrophilum was isolated from internal organs and skin ulcers of all dead fish in the 'Skin wounded' and the 'Non-intact skin mucus' groups, but from only 1 surviving fish in the 'Skin wounded' group. Low mortality (average $3 \%$ in the 3 groups) without internal or external signs of the disease occurred in the 'Control' groups during the experiment. Bacteria could not be isolated from these dead fish.

Where rainbow trout were exposed to 3 different dilutions of Flavobacterium psychrophilum, cumulative mortality reached $58 \%$ (replicates 47 and $67 \%$ ), $33 \%$ (replicates 26 and $40 \%$ ) and $28 \%$ (replicates 23 and $33 \%$ ) in the groups of fish bathed with $6.0 \times 10^{5}$ $6.0 \times 10^{4}$ and $6.0 \times 10^{2} \mathrm{CFU} \mathrm{ml}^{-1}$, respectively (Fig. $1 \mathrm{~b}$ ) F. psychrophilum was isolated from internal organs (spleen and/or kidney) and skin lesions of all dead fish. Low mortality (average $7 \%$; replicates 4 and $10 \%$ ) without internal or external signs of disease occurred in the 'Control' group during the experiment. Bacteria could not be isolated from these dead fish. 

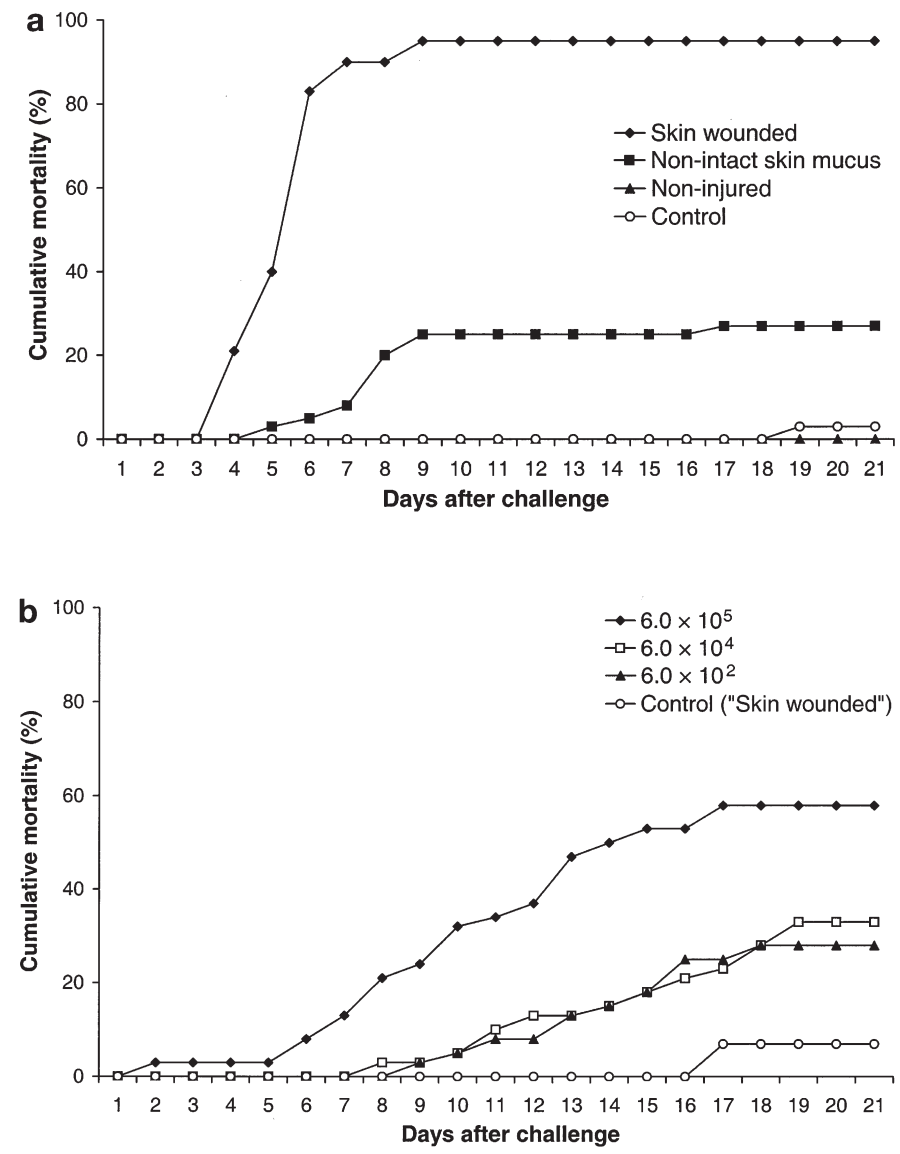

Fig. 1. Flavobacterium psychrophilum infecting Oncorhynchus mykiss. (a) Cumulative mortality of rainbow trout affected with artificial skin wound ('Skin wounded'), affected with skin mucus removal ('Non-intact skin mucus') and not affected ('Non-injured') and bath challenged with $3.8 \times 10^{6} \mathrm{CFU}$ $\mathrm{ml}^{-1}$ of $F$. psychrophilum strain T1-1. The values are averages from 2 replicates. The 'Control' group contained 3 groups of 20 fish each given the same treatment as the fish in the groups mentioned above but 'bathed' in water without F. psychrophilum. (b) Cumulative mortality of rainbow trout affected with artificial skin wound ('Skin wounded') and bath challenged with different doses of the F. psychrophilum CFU ml-1

\section{Cohabitation challenge}

Mortality and bacterial enumeration in the cohabitation challenge experiments of each treatment are averages from 2 replicates (Fig. 2). The donor fish (s.c. infected) began to die 4 to $5 \mathrm{~d}$ post-challenge and the cumulative mortality in the 'Skin wounded' group reached $80 \%$ (replicates 60 and 100\%), in the 'Nonintact skin mucus' group 90\% (replicates 80 and $100 \%$ ) and in the 'Non-injured' group $100 \%$. Dead donor fish from the beginning of the experiments showed necrosis and haemorrhage at the site of the injection, and in fish from the middle and the end of the experiment the skin necrosis had progressed into open lesions. Significant mortality (average $64 \%$; replicates 47 and $80 \%$ ) of recipient fish occurred only in the 'Skin wounded' group (Fig. 2a), and these fish showed deep, open lesions extending from the dermal incision point. Two recipient fish died in the 'Control' group. Flavobacterium psychrophilum was isolated from spleen and/or kidney and skin lesion of $93 \%$ and only from skin lesion of $7 \%$ of the dead donor fish. F. psychrophilum was isolated from internal organs and/or skin ulcer of $96 \%$ of dead recipient fish. Bacteria could not be isolated from dead fish from the 'Control' group. F. psychrophilum could not be isolated from surviving donor or recipient fish.

Flavobacterium psychrophilum cells were observed in the water samples 1 to $3 \mathrm{~d}$ after injection of the donor fish, and the highest numbers of F. psychrophilum cells were detected $7 \mathrm{~d}$ after injection in all 3 groups. After Day 9, F. psychrophilum could not be detected in the analysed water samples. F. psychrophilum were not observed in the 'Control' group aquarium during the experiment.

\section{Shedding rate experiments}

\section{Subcutaneous infection}

The shedding rate of Flavobacterium psychrophilum by s.c. infected fish was associated with the water temperature (Fig. 3a). At $4^{\circ} \mathrm{C} \mathrm{F}$. psychrophilum were not detected in the water until $14 \mathrm{~d}$ after infection, and the highest shedding rate by living fish occurred $18 \mathrm{~d}$ after infection. The cumulative mortality of infected fish was $67 \%$ (replicates 60, 60 and $80 \%$ ). At $11^{\circ} \mathrm{C} \mathrm{F}$. psychrophilum were detected $1 \mathrm{~d}$ after infection and the highest number of cells were observed $7 \mathrm{~d}$ after infection. The cumulative mortality of infected fish reached $60 \%$ (replicates 20, 60 and $100 \%$ ). At $15^{\circ} \mathrm{C} \mathrm{F}$. psychrophilum were present in the water after $3 \mathrm{~d}$, with the highest number of cells occurring $7 \mathrm{~d}$ after infection. The cumulative mortality of infected fish was $40 \%$ (replicates 20, 40 and 60\%). F. psychrophilum was not detected in the control aquaria, and mortality did not occur in the control groups during the experiments. F. psychrophilum was re-isolated from all organs of dead fish assayed, from organs of some surviving and from none of the control fish (Table 1). Dead fish showed skin necrosis and haemorrhages at the site of injection, and in some fish skin necrosis had progressed into open lesions. The numbers of $F$. psychrophilum released from dead fish were much higher compared to the number of cells shed by living fish, and F. psychrophilum were emitted for up to $80 \mathrm{~d}$ after death, when the experiment was terminated (Fig. 3b). 

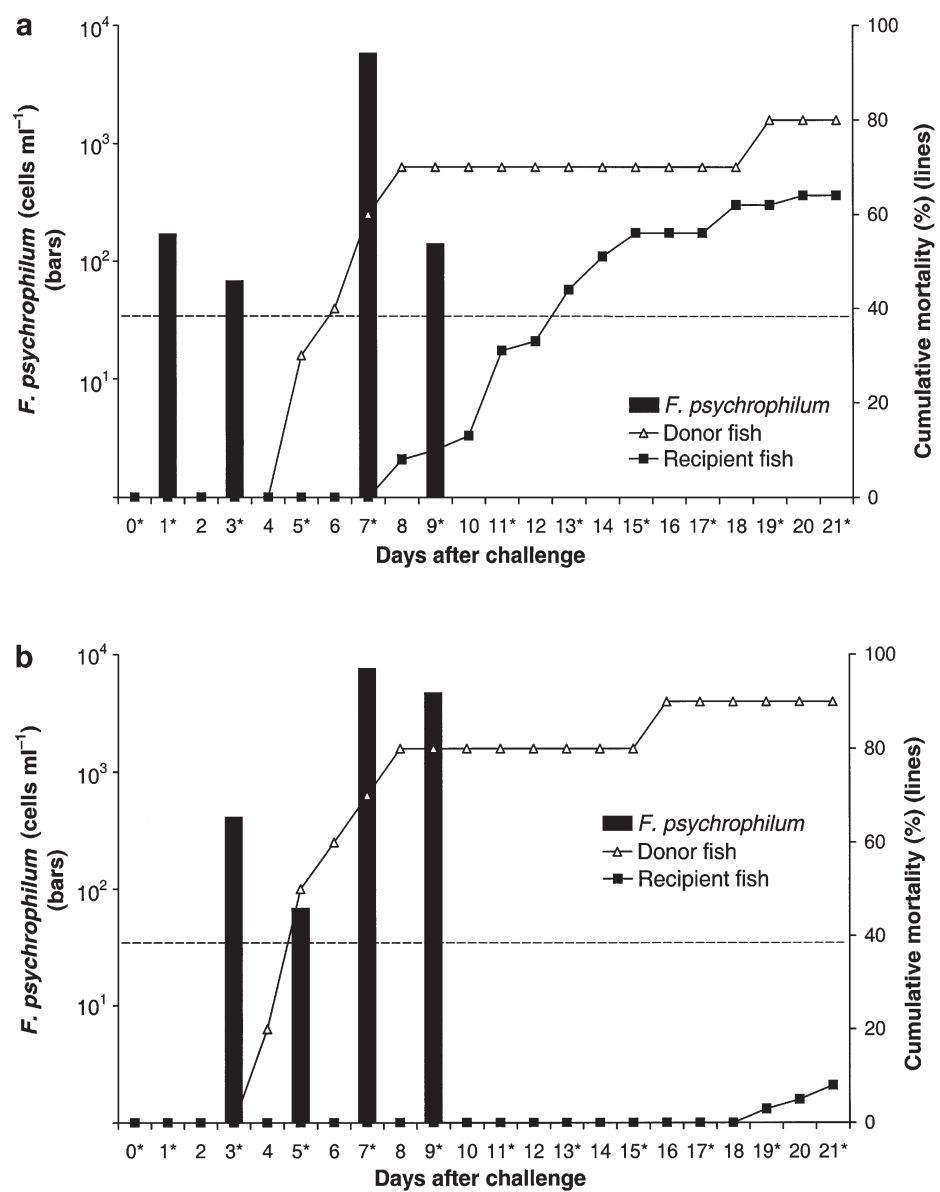

Intraperitonal infection

Flavobacterium psychrophilum cells (average $1.4 \times$ $10^{4}$ cells $^{-1}$ fish $^{-1}$, range 0 to $2.0 \times 10^{4}$ cells $^{-1}$ fish $^{-1}$ ) shed by i.p. infected fish were only detected in the water samples $3 \mathrm{~d}$ post-challenge. F. psychrophilum were not observed in the control aquaria. Mortality of the infected fish did not occur during $14 \mathrm{~d}$ of monitoring, and F. psychrophilum could not be isolated from kidney, spleen, eye, intestine or brain of surviving fish.

\section{Bath challenge}

Flavobacterium psychrophilum were not detected in any water samples in the shedding rate experiment with fish challenged by bathing in a bacterial suspension. Mortality of the experimental fish did not occur during $14 \mathrm{~d}$ of monitoring, and F. psychrophilum could not be isolated from the kidney, spleen, eye, intestine or brain of surviving fish.

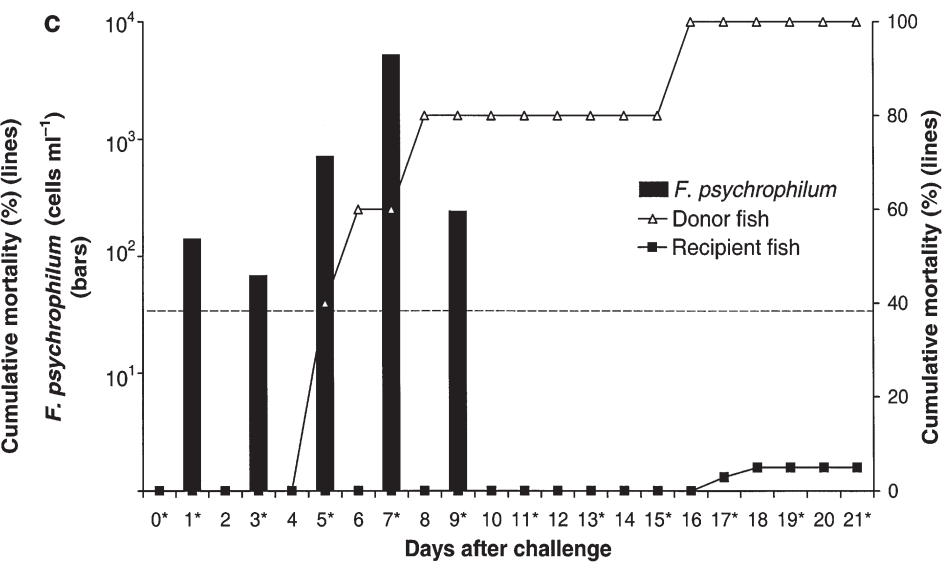

Fig. 2. Flavobacterium psychrophilum infecting Oncorhynchus mykiss. Cumulative mortality of donor and recipient fish in the cohabitation challenge experiment. The values are averages from 2 replicates. The recipient fish were treated in 3 different ways: (a) with artificial skin wound ('Skin wounded'), (b) with skin mucus removal ('Non-intact skin mucus'), (c) not-affected ('Noninjured'). *Sampling occasion for the estimation of the number of $F$. psychrophilum cells in the water. Dashed line: detection limit ( 34 cells $\mathrm{ml}^{-1}$ ) of the method used

Table 1. Flavobacterium psychrophilum infecting Oncorhynchus mykiss. Isolation of $F$. psychrophilum from subcutaneously injected dead, surviving and control fish. Results are expressed as number of fish positive for F. psychrophilum/ number of fish examined

\begin{tabular}{|c|c|c|c|c|}
\hline Group & Organ & $4^{\circ} \mathrm{C}$ & $11^{\circ} \mathrm{C}$ & $15^{\circ} \mathrm{C}$ \\
\hline \multirow[t]{6}{*}{ Dead } & Kidney & $5 / 5$ & $5 / 5$ & $6 / 6$ \\
\hline & Spleen & $5 / 5$ & $5 / 5$ & $6 / 6$ \\
\hline & Brain & $5 / 5$ & $5 / 5$ & $6 / 6$ \\
\hline & Side muscle $^{a}$ & $5 / 5$ & $5 / 5$ & $6 / 6$ \\
\hline & Intestine & $4 / 5$ & $4 / 5$ & $2 / 6$ \\
\hline & Eye & $3 / 5$ & $3 / 5$ & $3 / 6$ \\
\hline \multirow[t]{6}{*}{ Surviving } & Kidney & $2 / 5$ & $0 / 6$ & $0 / 9$ \\
\hline & Spleen & $2 / 5$ & $0 / 6$ & $0 / 9$ \\
\hline & Brain & $1 / 5$ & $0 / 6$ & $0 / 9$ \\
\hline & Side muscle ${ }^{a}$ & $5 / 5$ & $3 / 6$ & $2 / 9$ \\
\hline & Intestine & $0 / 5$ & $2 / 6$ & $0 / 9$ \\
\hline & Eye & $0 / 5$ & $0 / 6$ & $0 / 9$ \\
\hline \multirow[t]{6}{*}{ Control } & Kidney & $0 / 10$ & $0 / 10$ & $0 / 10$ \\
\hline & Spleen & $0 / 10$ & $0 / 10$ & $0 / 10$ \\
\hline & Brain & $0 / 10$ & $0 / 10$ & $0 / 10$ \\
\hline & Side muscle $^{a}$ & $0 / 10$ & $0 / 10$ & $0 / 10$ \\
\hline & Intestine & $0 / 10$ & $0 / 10$ & $0 / 10$ \\
\hline & Eye & $0 / 10$ & $0 / 10$ & $0 / 10$ \\
\hline
\end{tabular}



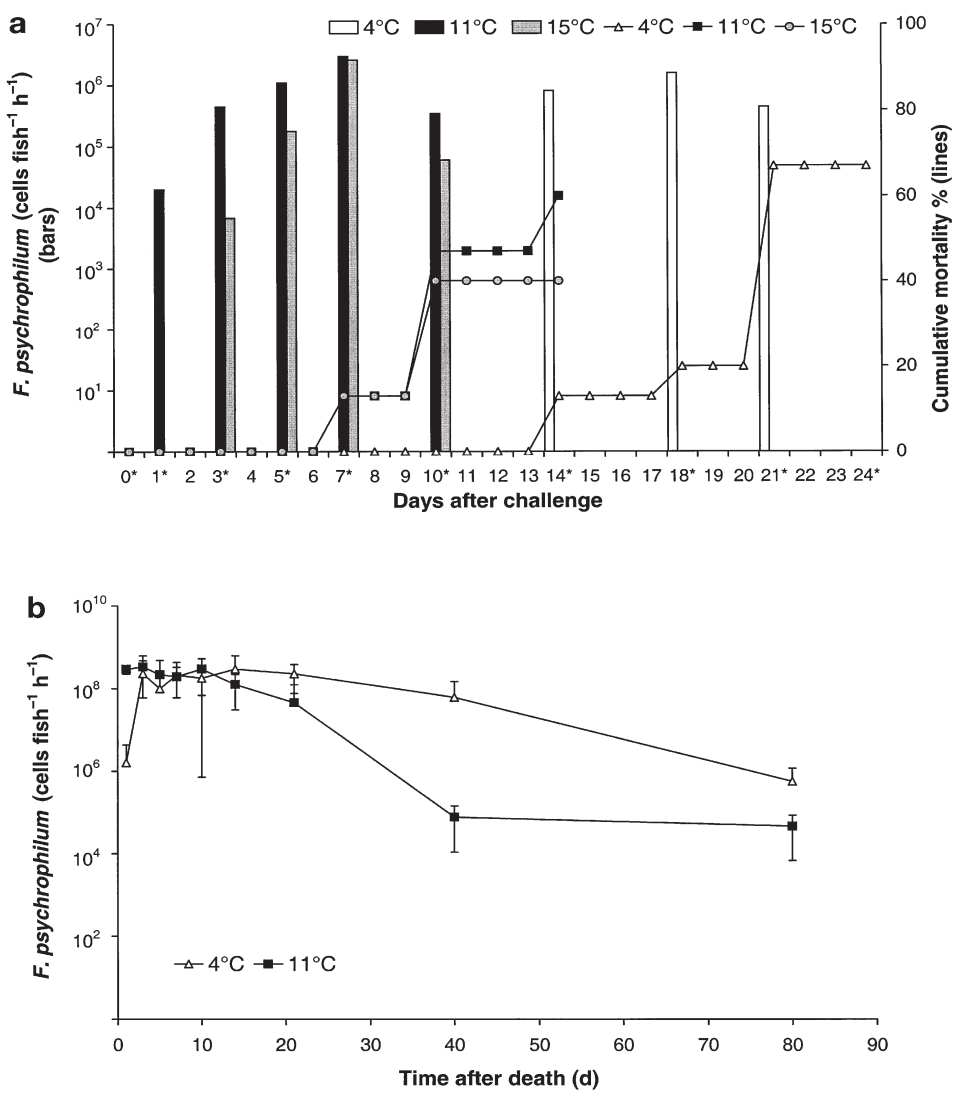

Fig. 3. Flavobacterium psychrophilum infecting Oncorhynchus mykiss. (a) Shedding rate of F. psychrophilum cells by subcutaneously infected rainbow trout held at different temperatures and cumulative mortality of infected fish $(\mathrm{n}=15$ fish temperature ${ }^{-1}$ ). ${ }^{*}$ Sampling occasions for the estimation of the average number of $F$. psychrophilum cells in the water. The experiment was terminated $14 \mathrm{~d}$ after injection at 11 and $15^{\circ} \mathrm{C}$ and $24 \mathrm{~d}$ after injection at $4^{\circ} \mathrm{C}$. (b) Release of $F$. psychrophilum from dead rainbow trout held at 4 and $11^{\circ} \mathrm{C}$. Error bars $=$ standard deviation

\section{Oral route of transfer}

The total number of Flavobacterium psychrophilum cells on and in Daphnia magna was estimated to be $1.3 \times 10^{5}$ cells $D$. magna ${ }^{-1}$ by epifluorescence microscopy (Fig. 4) and $1.6 \times 10^{5}$ CFU D. magna ${ }^{-1}$ by plate count. Since each fish was fed with $5 \mathrm{D}$. magna the infection dose averaged $7.5 \times 10^{5} \mathrm{~F}$. psychrophilum cells fish ${ }^{-1}$. In the immunohistological sections of $D$. magna, F. psychrophilum cells could clearly be detected in the gastrointestinal tract.

A total number of 31 infected fish, 8 negative control fish and 3 positive control fish were immunohistochemically examined for the presence of Flavobacterium psychrophilum in different organs. Of the infected fish $F$. psychrophilum was detected in the stomach of 1 specimen sacrificed $2 \mathrm{~h}$ after feeding. Intact F. psy- chrophilum were not observed in any other sample taken from fish fed with infected Daphnia magna. From the microscopical examination of gastrointestinal tract sections from challenged rainbow trout it was concluded that F. psychrophilum were digested. Numerous fluorescing particles, which were interpreted as cell wall fragments containing binding sites for the polyclonal antibodies, were observed in $79 \%(n=14)$ of the fish sacrificed first, i.e. $2 \mathrm{~h}$ post-challenge, in $33 \%(\mathrm{n}=9)$ of the examined fish sacrificed after $1 \mathrm{~d}$, but were totally absent in sections made from fish sacrificed $7 \mathrm{~d}$ post-challenge $(\mathrm{n}=8)$. Intact $F$. psychrophilum cells were detected only on sections made from the spleen, intestine, liver, heart and kidney of i.p. infected positive control fish. Bacteria or fluorescent binding sites were not observed on slices made on tissues from fish fed with $D$. magna without F. psychrophilum. Three out of a total of 75 orally challenged fish, 2 out of 30 negative control fish and 15 out of 18 positive control fish died during the experiment. F. psychrophilum could not be detected in the orally challenged fish and negative control fish using immunostaining of different organs. F. psychrophilum was detected in the positive control fish.

\section{DISCUSSION}

In the present study skin and skin mucus abrasion was found to enhance the invasion of Flavobacterium psychrophilum into the affected fish in bath and cohabitation challenge, but oral transfer of the bacteria using Daphnia magna as a vector was not demonstrated. The shedding rate of F. psychrophilum by infected fish was associated with water temperature.

The double-staining technique used in the present study proved to be a fast and simple method for the detection of Flavobacterium psychrophilum from water samples. Although a slight non-specific cross-reaction occasionally occurred between non-F. psychrophilum and antibodies of the primary or the secondary antiserum, F. psychrophilum was easily distinguished based on the size and the morphology of the cells and the fluorescence intensity of stained cells.

The results of the present study demonstrated that skin incision and to some degree non-intact skin mucus layer seemed to enhance the invasion of Flavobacterium psychrophilum into rainbow trout. Attempts to infect fish with F. psychrophilum without artificial skin incision, or partially removed skin mucus before bath challenge, failed in the present study. Similar results were previously reported for coho salmon Oncorhyn- 


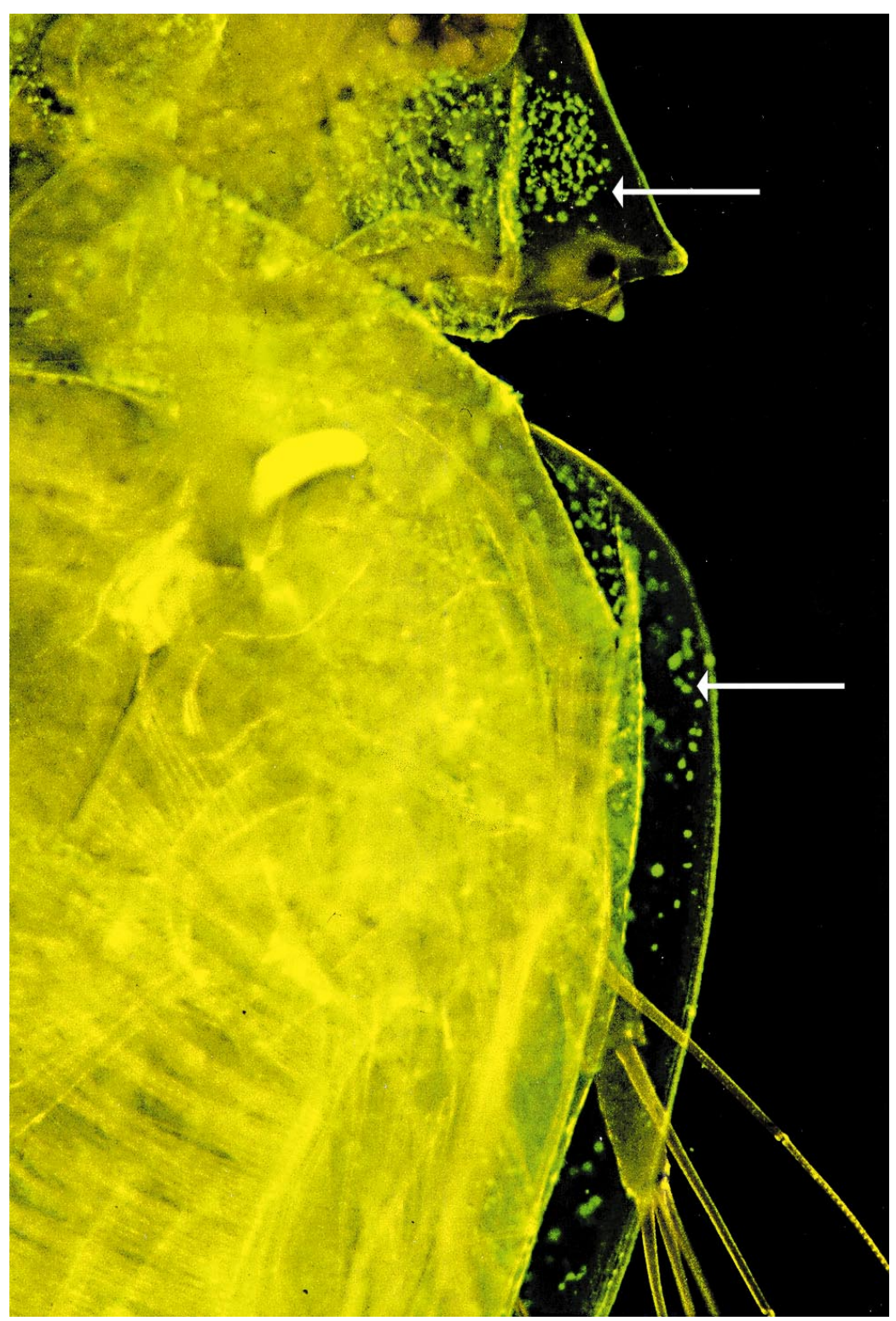

Fig. 4. Daphnia magna after incubation in a suspension of Flavobacterium psychrophilum. Indirect immunofluorescence technique demonstrating F. psychrophilum (dark green, indicated by arrows) adhering to the outer surface of D. magna (magnification $40 \times$ )

chus kisutch (Borg 1948). It has also been shown that skin alterations in the fish, due to formalin bath treatment, seem to facilitate the introduction of F. psychrophilum into rainbow trout, subsequently causing mortality (Madsen \& Dalsgaard 1999). Repeated treatment of juvenile rainbow trout with a therapeutic concentration of formalin affects the skin of the fish, causing a significantly thinned epidermis (Sanchez et al. 1998). However, in other studies F. psychrophilum has experimentally been introduced into both coho salmon and rainbow trout without using any mechanical or chemical treatment of the skin (Holt 1987, Rangdale 1995). Instead an extended challenge time ( 5 and $10 \mathrm{~h}$ ) has been used (Rangdale 1995), but in 1 study the results were difficult to interpret and the authors concluded that the bath challenge technique was not a reliable method (Holt 1987). The results of the present study as well as other previous studies indicate that skin and skin mucus of rainbow trout play an important role in the defence against F. psychrophilum. The non-specific mechanisms of the immune system located in the epithelial surfaces of the fish, including skin, gills and gut, such as lysozyme and phagocytic cells, are reported to be of vital importance for the defence against invading microorganisms into fish fry (Tatner 1996, Yano 1996). Brown et al. (1997) reported that F. psychrophilum was not as susceptible to lysozyme as was Aeromonas salmonicida. In farmed fish, for example, skin parasite infections, vaccination, therapeutic use of formalin, high ammonia level, gas supersaturation in the rearing water (gas bubble disease) and handling of the fish (e.g. grading) can cause damage to the skin, bypass the non-specific mechanisms of the immune system and thus promote the invasion of $F$. psychrophilum into the fish. Wood (1974) suggested that a high water flow in rearing tanks might physiologically weaken or physically abrade the coho salmon fry, rendering them more susceptible to F. psychrophilum infection. It is thus recommended that good management of the farmed rainbow trout fry will significantly decrease the risk for a disease outbreak of RTFS. Skin damage has also been reported to facilitate the entrance of other pathogens into fish, e.g. Vibrio anguillarum and typical Aeromonas salmonicida into Atlantic salmon Salmo salar (Svendsen \& Bøgwald 1997) and atypical $A$. salmonicida into flounder Platichthys flesus (Wiklund 1995).

In the cohabitation challenge experiment significant mortality among the recipient fish occurred only in the 'Skin wounded' group. Bacterial levels around $10^{2}$ cells $\mathrm{ml}^{-1}$ at start of the cohabitation experiments (Fig. 2a) resulted in a much higher mortality $(64 \%)$ than that $(28 \%)$ in the bath challenge experiment with $6.0 \times$ 
$10^{2} \mathrm{CFU} \mathrm{ml}{ }^{-1}$. A continuous challenge of the recipient fish in the cohabitation experiment with bacterial concentrations between $10^{2}$ and $10^{4}$ cells $\mathrm{ml}^{-1}$ for several days may have contributed to the high mortality. The results support the observation by Borg (1948), who was also able to infect only artificially scarified recipient coho salmon in a cohabitation challenge experiment. In contrast, Madsen \& Dalsgaard (1999) infected only a few recipient rainbow trout, although the fish were marked by cutting off the adipose fin, thus opening an invasion route for the bacteria.

Interestingly, Flavobacterium psychrophilum were not detected (absent or below detection limit) in water samples after Day 9, once the mortality (from Day 4 to Day 8) of the s.c. infected donor fish had ceased and dead fish had been removed from the aquaria. Although the recipient fish in the 'Skin wounded' group showed deep lesions at the point where the skin was wounded, these fish did not seem to shed detectable numbers (detection limit 34 cells $\mathrm{ml}^{-1}$ ) of $F$. psychrophilum cells into the water. These results may indicate that fish infected by F. psychrophilum from the water emit low numbers of bacterial cells to the surrounding tank water. The results from the cohabitation experiments support the results from the bath challenge experiments that introduction of $F$. psychrophilum cells into fish is greatly enhanced by damage to the skin; this is also the case if there is a continuous moderate number $\left(10^{2}\right.$ to $10^{3}$ cells $\left.\mathrm{ml}^{-1}\right)$ of $F$. psychrophilum for several days. Our results are comparable to previous studies with typical Aeromonas salmonicida by Enger et al. (1992), who found that the release of the bacterium into the water was dramatically reduced once the i.p. infected donor fish had died and was removed from the experiment. The recipient fish did not seem to release $A$. salmonicida into the water to the same extent as the donor fish. Enger et al. (1992) summarised that i.p. injected fish seemed to release more pathogens into the environment compared to fish that received the infection from other diseased cohorts.

There are no previous reports on the shedding rate of Flavobacterium psychrophilum by infected fish. The results of the present study suggest that F. psychrophilum are shed by infected living fish into the water prior to death $\left(10^{3}\right.$ to $10^{6}$ cells fish $\left.{ }^{-1} \mathrm{~h}^{-1}\right)$. Additionally, very high numbers $\left(10^{4}\right.$ to $10^{8}$ cells fish $\left.{ }^{-1} \mathrm{~h}^{-1}\right)$ of $F$. psychrophilum can be released from a dead fish for an extended period of time (>80 d). According to the results from the shedding rate studies; it is suggested that in commercial fish farms as well as in virulence experiments an efficient removal of dead and moribund fish from tanks should be performed in order to decrease the number of $F$. psychrophilum in the water and thus diminish the infection pressure.
The shedding of Flavobacterium psychrophilum by s.c. infected rainbow trout and the mortality of the fish was associated with the water temperature. Mortality of infected fish and shedding of $F$. psychrophilum into the water began later at $4^{\circ} \mathrm{C}$ than at 11 and $15^{\circ} \mathrm{C}$. This could be the result of a lower metabolic rate of the bacteria and/or fish and thus a slower spreading of the bacteria in the fish at $4^{\circ} \mathrm{C}$ than at higher temperatures. Re-isolation of F. psychrophilum from tissue of surviving fish (challenged with s.c. injection) without any external or internal disease signs indicates possible development of an asymptomatic carrier-state. F. psychrophilum was isolated with higher prevalence from tissues and organs of surviving fish from the experiment done at $4^{\circ} \mathrm{C}$ than at 11 and $15^{\circ} \mathrm{C}$ (Table 1). The results suggest that $F$. psychrophilum can survive at low water temperature (around $4^{\circ} \mathrm{C}$ ) in low numbers in different organs and tissues of fish without causing disease, indicating a slow or incomplete non-specific immune response against F. psychrophilum in the challenged fish. A stress factor affecting the infected fish may subsequently initiate a disease outbreak.

To our knowledge, there are rather few previous studies on the shedding of pathogenic bacteria by infected fish. Rose et al. (1989) reported that intramuscularly challenged Atlantic salmon (weight $23 \mathrm{~g}$ ) shed between $5.7 \times 10^{5}$ and $2.1 \times 10^{7} \mathrm{CFU}$ of Aeromonas salmonicida fish ${ }^{-1} \mathrm{~h}^{-1}$. These values are higher than those obtained in our study $\left(6.8 \times 10^{3}\right.$ to $3.0 \times 10^{6}$ cells of Flavobacterium psychrophilum fish ${ }^{-1} \mathrm{~h}^{-1}$ ). In most other studies the number of cells emitted from infected fish per unit time was not evaluated; instead the number of bacteria per water volume was measured mainly in order to optimise cohabitation experimental procedures (McCarthy 1977, Michel 1980, Enger et al. 1992, McKibben \& Pascho 1999). Unfortunately, we have not been able to find any studies on the release of bacterial pathogens from naturally infected fish.

In the shedding rate experiment done by i.p. injection of $1.3 \times 10^{5} \mathrm{CFU}$ fish $^{-1}$ of Flavobacterium psychrophilum, mortality did not occur, although $3.2 \times$ $10^{4} \mathrm{CFU}$ fish $^{-1}$ was able to produce $60 \%$ cumulative mortality among s.c. infected fish in the experiment at the same temperature. This observation supports the findings made by Holt (1987) suggesting that a considerably higher number of bacteria were required to kill $50 \%$ of coho salmon infected i.p. ( $\mathrm{LD}_{50}=1.34 \times 10^{6} \mathrm{cells}$ ) than by intramuscular injections $\left(\mathrm{LD}_{50}=8.2 \times 10^{4}\right.$ cells $)$ and s.c. injections $\left(\mathrm{LD}_{50}=1.14 \times 10^{5}\right.$ cells $)$. It is obvious that rainbow trout defence mechanisms in the peritoneal cavity neutralised the injected F. psychrophilum cells, thus preventing colonisation.

There are no previous reports on challenge of rainbow trout with Flavobacterium psychrophilum using oral infection through live vector organisms. Intact $F$. 
psychrophilum were not observed in organs or tissues of the orally challenged fish, except in the stomach of 1 fish. However, numerous fluorescent particles, interpreted as bacterial cell wall fragments, were frequently present in sections of the gastrointestinal tract of examined fish. The $\mathrm{pH}$ in the stomach of feeding fish is considered to be between 2 and 5 (Jobling \& Hjelmeland 1992). In a previous study it was shown that the majority of F. psychrophilum in sterile water at $\mathrm{pH} 4.01$ were killed after $1 \mathrm{~d}$, whereas the bacteria survived in sterile tap water at pH 5 to 7 (Lorenzen 1994). In the present study, the F. psychrophilum in the intestine of Daphnia magna were hypothesised to be protected from the low $\mathrm{pH}$ in the stomach of the fish. However, partly or completely digested $D$. magna were observed in several slides of fish stomach, which indicates that $F$. psychrophilum were exposed to the low $\mathrm{pH}$. The number of intact bacterial cells possibly transported further to the intestine seems to have been too few for a successful invasion and infection of the challenged fish. The pathogenicity of the strain used in the present study has been previously documented (for fish weight $1.1 \mathrm{~g}$ ) (Madsen \& Dalsgaard 1999), but the fish of our study were 2 to $4 \mathrm{~g}$ and probably possessed a higher immunocompetence, thus giving a better protection against $F$. psychrophilum.

As a summary of this study, it can be concluded that skin wounds markedly enhanced the invasion of Flavobacterium psychrophilum into rainbow trout juveniles (1 to $2 \mathrm{~g}$ ) both in bath challenge and cohabitation experiments. In addition, partially removed skin mucus layer facilitated the entrance of F. psychrophilum into the fish. This indicates the significance of intact skin and mucus layer in inhibiting the invasion processes of $F$. psychrophilum. It is also suggested that the ingestion of the pathogen through living vectors is not an important invasion route for $F$. psychrophilum. The present study suggest the importance of management measurements in the fish farms, i.e. removal of dead and moribund fish from tanks in order to decrease the number of F. psychrophilum cells in rearing water and thus diminishing the infection pressure on uninfected fish, and avoidance of unnecessary handling (e.g. grading) and if possible, parasite infections to prevent damage to the skin.

Acknowledgements. The authors are grateful to the staff of the Fish Disease Laboratory, Danish Institute for Fisheries Research, for skilful technical assistance. This study was supported by Academy of Finland (Grant No. 57957).

\section{LITERATURE CITED}

Borg AF (1948) Studies on myxobacteria associated with diseases in salmonid fishes. PhD thesis, University of Washington, Seattle

Brown LL, Cox WT, Levine RP (1997) Evidence that the causal agent of bacterial cold-water disease Flavobacterium psychrophilum is transmitted within salmonid eggs. Dis Aquat Org 29:213-218

Bruno DW, Poppe TT (1996) A colour atlas of salmonid diseases. Academic Press, London

Bullock GL, Stuckey HM (1977) Ultraviolet treatment of water for destruction of five Gram-negative bacteria pathogenic to fishes. J Fish Res Board Can 34:1244-1249

Ekman E, Börjeson H, Johansson N (1999) Flavobacterium psychrophilum in Baltic salmon Salmo salar brood fish and their offspring. Dis Aquat Org 37:159-163

Elendt BP, Bias WR (1990) Trace nutrient deficiency in Daphnia magna cultured in standard medium for toxicity testing. Effects of the optimization of culture conditions on life history parameters of D. magna. Water Res 24:1157-1167

Ellis AE (1981) Nonspecific defense mechanisms in fish and their role in disease processes. Dev Biol Stand 49:337-352

Enger Ø, Gunnlaugsdottir B, Thorsen BK, Hjeltnes B (1992) Infectious load of Aeromonas salmonicida subsp. salmonicida during the initial phase of a cohabitant infection experiment with Atlantic salmon, Salmo salar L. J Fish Dis 15:425-430

Fletcher TC (1982) Non-specific defence mechanisms of fish. Dev Comp Immunol Suppl 2:123-132

Grisez L, Chair M, Sorgeloos P, Ollevier F (1996) Mode of infection and spread of Vibrio anguillarum in turbot Scophthalmus maximus larvae after oral challenge through live feed. Dis Aquat Org 26:181-187

Hoff KA (1988) Rapid and simple method for double staining of bacteria with 4',6-diamidino-2-phenylindole and fluorescein isothiocyanate-labeled antibodies. Appl Environ Microbiol 54:2949-2952

Holt RA (1987) Cytophaga psychrophila, the causative agent of bacterial cold-water disease in salmonid fish. PhD thesis, Oregon State University, Corvallis

Ingram GA (1980) Substances involved in the natural resistence of fish to infection-a review. J Fish Biol 16:23-60

Jobling M, Hjelmeland K (1992) Ernæring og fordøyelse. In: Døving K, Reimers E (eds) Fiskens fysiologi. John Grieg Forlag AS, Stavanger, p 234-257

Lancefield RC, McCarty M, Everly WN (1975) Multiple mouse-protective antibodies directed against group B streptococci. Special reference to antibodies effective against protein antigens. J Exp Med 142:165-179

Lorenzen E (1994) Studies on Flexibacter psychrophilus in relation to rainbow trout fry syndrome (RTFS). PhD thesis, National Veterinary Laboratory, Århus, and Royal Veterinary and Agricultural University, Copenhagen

Lorenzen E, Karas N (1992) Detection of Flexibacter psychrophilus by immunofluorescence in fish suffering from fry mortality syndrome: a rapid diagnostic method. Dis Aquat Org 13:231-234

Madsen L, Dalsgaard I (1999) Reproducible methods for experimental infection with Flavobacterium psychrophilum in rainbow trout Oncorhynchus mykiss. Dis Aquat Org 36:169-176

McCarthy DH (1977) Some ecological aspects of the bacterial fish pathogen Aeromonas salmonicida. In: Skinner FA, Shewan JM (eds) Aquatic microbiology. The Society for Applied Bacteriology symposium series no. 6, Academic Press, London, p 299-324

McKibben CL, Pascho RJ (1999) Shedding of Renibacterium salmoninarum by infected chinook salmon Oncorhynchus tschawytscha. Dis Aquat Org 38:75-79

Michel C (1980) Development of bacteria in fish and in water during a standardized experimental infection of rainbow trout (Salmo gairdneri) with Aeromonas salmonicida. 
In: Ahne W (ed) Fish diseases. Third COPRAQ-Session. Springer-Verlag, Berlin, p 94-97

Rangdale RE (1995) Studies on rainbow trout fry syndrome (RTFS). PhD thesis, Ministry of Agriculture, Fisheries and Food, Weymouth, and University of Stirling

Rose AS, Ellis AE, Munro ALS (1989) The infectivity by different routes of exposure and shedding rates of Aeromonas salmonicida subsp. salmonicida in Atlantic salmon, Salmo salar L., held in sea water. J Fish Dis 12:573-578

Sanchez JG, Speare DJ, Sims DE, Johnson GJ (1998) Morphometric assessment of epidermal and mucous-biofilm changes caused by exposure of trout to chloramine- $\mathrm{T}$ or formalin treatment. J Comp Pathol 118:81-87

Svendsen YS, Bøgwald J (1997) Influence of artificial wound and non-intact mucus layer on mortality of Atlantic salmon (Salmo salar L.) following a bath challenge with Vibrio anguillarum and Aeromonas salmonicida. Fish Shellfish Immunol 7:317-325

Editorial responsibility: David Bruno,

Aberdeen, Scotland, UK
Tatner MF (1996) Natural changes in the immune system of fish. In: Iwama G, Nakanishi $T$ (eds) The fish immune system; organism, pathogen, and environment. Academic Press, London, p 255-287

Wiklund T (1995) Virulence of 'atypical' Aeromonas salmonicida isolated from ulcerated flounder Platichthys flesus. Dis Aquat Org 21:145-150

Wiklund T, Madsen L, Bruun MS, Dalsgaard I (2000) Detection of Flavobacterium psychrophilum from fish tissue and water samples by PCR amplification. J Appl Microbiol 88: 299-307

Wood JW (1974) Diseases of Pacific salmon, their prevention and treatment, 2nd edn. State of Washington, Department of Fisheries, Hatchery Division, Olympia, WA, p 22-24

Yano $T$ (1996) The nonspecific immune system: humoral defense. In: Iwama G, Nakanishi T (eds) The fish immune system; organism, pathogen, and environment. Academic Press, London, p 106-157

Submitted: March 13, 2000; Accepted: July 25, 2000

Proofs received from author(s): September 18, 2000 